\title{
Characteristics of pediatric patients operated of aortic coarctation in the years 2009-2018 at the National Institute of Cardiology Ignacio Chávez
}

\section{Características de los pacientes pediátricos operados de coartación aórtica en los años 2009 a 2018 en el Instituto Nacional de Cardiología Ignacio Chávez}

\section{Fernando A. Muralles-Castillo*}

Department of Pediatric Cardiology, Instituto Nacional de Cardiología Ignacio Chávez, Faculty of Medicine, Postgraduate Studies Division, Mexico City, Mexico

\begin{abstract}
Objective: The objective of the study was to determine the radiographic, electrocardiographic, angiographic, and surgical characteristics of the patients operated with aortic coarctation at the Ignacio Chavez National Institute of Cardiology between 2009 and 2018. Methods: The variables considered relevant for the study were collected from the electronic file, recorded in the previously designed Excel capture sheet. Various radiographic, electrocardiographic, angiographic, and surgical variables were analyzed. Post-surgical clinical evolution, complications, and requirements for interventional or surgical procedures were assessed, and the response to these as well as the different outcomes was assessed. Results: $A$ total of 187 patient surgeries are reported from 2 days of age to 12 years, where the radiological, electrocardiographic characteristics, and presentation age are mentioned. The total number of deaths in the 9 years was 17 cases, which were mostly (94\%) before the $1^{\text {st }}$ year of life. The most commonly used surgical technique (90\%) was extended coarctectomy with term-terminal anastomosis. The recorded post-operative complications were in descending order: ventricular failure, systemic arterial hypertension, renal failure that required peritoneal dialysis, etc. Conclusions: The registered population that required surgical intervention at the National Institute of Cardiology was mostly a minor infant with a median of 3 months in their surgery age. In view of the surgical technique used, the one that had better results and that did not show a significant association with the number of deaths was the extended coarctectomy with end-to-end anastomosis.
\end{abstract}

Key words: Coarctaction of the aorta. Coarctectomy. Infant. Catheterization. Ventricular failure. Arterial hypertension.

\section{Resumen}

Objetivo: Determinar las características radiográficas, electrocardiográficas, angiográficas y quirúrgicas de los pacientes operados con coartación aórtica en el Instituto Nacional de Cardiología Ignacio Chávez entre los años 2009 y 2018. Métodos: Se recabaron del expediente electrónico las variables consideradas relevantes para el estudio y se registraron en la hoja de captura Excel previamente diseñada. Se analizaron diversas variables radiográficas, electrocardiográficas, angio-

Correspondence:

${ }^{\star}$ Fernando A. Muralles-Castillo

E-mail: fernando.muralles@ hotmail.com
Available online: 02-03-2021 Arch Cardiol Mex (Eng). 2020;90(4):400-405 www.archivoscardiologia.com 2604-7063 / @ 2020 Instituto Nacional de Cardiología Ignacio Chávez. Published by Permanyer. This is an open access article under the CC BY-NC-ND license (http://creativecommons.org/licenses/by-nc-nd/4.0/). 
gráficas y quirúrgicas. Se valoró la evolución clínica posquirúrgica, complicaciones, requerimiento de procedimientos intervencionistas o quirúrgicos, y se valoró la respuesta a estos y también los diferentes desenlaces. Resultados: Se reportan 187 cirugías de pacientes desde los 2 días de vida hasta los 12 años, en donde se mencionan las características radiológicas, electrocardiográficas y edad de presentación. El total de fallecimientos en los 9 años fue de 17 casos, los cuales en su gran mayoría (94\%) fueron antes del primer año de vida. La técnica quirúrgica más utilizada (90\%) fue la coartectomía extendida con anastomosis terminoterminal. Las complicaciones posquirúrgicas registradas fueron en orden descendente: insuficiencia ventricular izquierda, hipertensión arterial sistémica, insuficiencia renal que requirió diálisis peritoneal, etc. Conclusiones: La población registrada que requirió una intervención quirúrgica en el Instituto Nacional de Cardiología fue en su mayoría "lactante menor», con una mediana de 3 meses de edad en el momento de la cirugía. Respecto a la técnica quirúrgica empleada, la que tuvo mejores resultados y que no demostró tener una asociación significativa con el número de defunciones fue la coartectomía extendida con anastomosis terminoterminal.

Palabras clave: Coartación aórtica. Coartectomía. Lactante. Cateterismo. Insuficiencia ventricular. Hipertensión arterial.

\section{Introduction}

Coarctation of the aorta is one of the congenital heart diseases that frequently reduce life expectancy and, given its complications, it deserves constant monitoring of the disease, since, in the long term, it may develop strokes, systemic arterial hypertension, and coronary artery diseases ${ }^{1}$. This disease accounts for between 5 and $7 \%$ of all congenital heart diseases ${ }^{1,2}$. Its prevalence is 0.2 per 1000 live births, with a predominance of the male gender ${ }^{3}$.

Injury in coarctation of the aorta occurs due to thickening of the aortic medial layer and intimal hyperplasia, and its location is on the descending aorta posterior wall after the origin of the left subclavian artery ${ }^{3}$. Narrowing can be located at the thoracic or abdominal portion of the aortic trajectory. According to the age at presentation, there will be areas of cystic necrosis of the aortic medial layer. According to embryological development, the left obstructive lesions produce this narrowing, and it also could be due to the presence of ectopic ductal tissue in the aorta at the level of the isthmus that constricts at the moment of ductus arteriosus closure ${ }^{3}$.

\section{Material and methods}

- Material. The resources that were used for carrying out the study were predesigned Excel spreadsheet, computer with Microsoft Office 2016 package, version 15.2, SPSS Statistical Package v.23, and National Institute of Cardiology Ignacio Chávez electronic medical record.

- Methods. Patient diagnosis was established by history and physical examination, as well as radiological and electrocardiographic studies, based on congenital heart disease segmental sequential analysis carried out by a group of experts of the National Institute of Cardiology Ignacio Chávez Department of Pediatric Cardiology.

The decision on the requirement and performance of surgery with the employed technique was made by joint evaluation of each case between the department of pediatric cardiology and the department of pediatric cardiovascular surgery, through medical-surgical clinical sessions, where clinical, radiographic, electrocardiographic, and angiographic variables were evaluated.

Patients who met the selection criteria were identified. The variables that were considered relevant to the study were collected from the electronic medical record and were recorded in the previously designed Excel capture spreadsheet, to finally perform the statistical analysis that was planned to report the obtained results.

\section{Results}

One hundred and eighty-seven patients diagnosed with coarctation of the aorta who underwent surgery in the period comprised between 2009 and 2018 were included. Median age was 3 months (minimum 2 days, maximum 11 years). About $64.2 \%$ of the patients were male. The most common diagnosis associated with coarctation of the aorta was patent ductus arteriosus in $57.2 \%(n=107)$ of patients followed by aortic arch hypoplasia in $50.3 \%(n=94)$ and pulmonary arterial hypertension in $39.6 \%(n=74)$. Table 1 shows the demographic description of the sample.

Patients were preoperatively evaluated with chest $X$-ray and electrocardiogram. The most frequently detected finding on chest X-ray was cardiomegaly in $93 \%$ ( $n=174)$ of patients followed by venocapillary congestion in $4.8 \%(n=9)$. On the electrocardiogram, the majority, $35.8 \%(n=67)$, showed no important changes, 
Table 1. Demographic description of the sample $(n=187)$

\begin{tabular}{|c|c|}
\hline Characteristic & n (\%) \\
\hline Age (years)* & $0.25(0.005-11)$ \\
\hline Male gender, n (\%) & $120(64.2)$ \\
\hline $\begin{array}{l}\text { Associated diagnosis, } \mathrm{n}(\%) \\
\text { Transposition of the great arteries } \\
\text { Patent ductus arteriosus } \\
\text { Aortic stenosis } \\
\text { Shone complex } \\
\text { Double outlet right ventricle } \\
\text { Isthmus hypoplasia } \\
\text { Transverse arch hypoplasia } \\
\text { Aortic arch hypoplasia } \\
\text { Ventricular septal defect } \\
\text { Atrial septal defect } \\
\text { Pulmonary arterial hypertension } \\
\text { Down's syndrome } \\
\text { Aberrant subclavian artery } \\
\text { Heart failure }\end{array}$ & $\begin{aligned} & 12(6.4) \\
& 107(57.2) \\
& 8(4.3) \\
& 1(0.5) \\
& 5(2.7) \\
& 27(14.4) \\
& 2(1.1) \\
& 94(50.3) \\
& 63(33.7) \\
& 15(8) \\
& 74(39.6) \\
& 5(3.7) \\
& 7(3.7) \\
& 32(17.1)\end{aligned}$ \\
\hline
\end{tabular}

*Non-parametric distribution; median, minimum, and maximum are reported.

Table 2. Pre-surgical evaluation $(n=187)$

\begin{tabular}{|l|c|}
\hline Characteristic & $\mathbf{n}(\%)$ \\
\hline $\begin{array}{l}\text { Chest X-ray, n (\%) } \\
\text { Cardiomegaly }\end{array}$ & $174(93)$ \\
Roesler sign & $2(1.1)$ \\
Venocapillary congestion & $9(4.8)$ \\
Inverted 3 sign & $2(1.1)$ \\
No changes & $1(0.5)$ \\
\hline Electrocardiogram & \\
No changes & $67(35.8)$ \\
\hline Left ventricular hypertrophy & $44(23.5)$ \\
Right ventricular hypertrophy & $65(34.7)$ \\
Not performed & $2(1.1)$ \\
Right atrial hypertrophy & $27(14.4)$ \\
\hline
\end{tabular}

but $34.7 \%$ ( $n=34.7 \%$ ) showed right ventricular hypertrophy, and $23.5 \%(n=44)$, left ventricular hypertrophy. The rest of the findings are shown in table 2.

About $31 \%$ of the patients ( $n=58$ ) underwent previous catheterization, which in $45 \%(n=26)$ of the patients was only diagnostic, in $40 \%(n=23)$, aortic angioplasty was performed and, in three patients, aortic valvuloplasty was performed.

The most widely used surgical technique was extended coarctectomy with end-to-end anastomosis, which was performed in $91.4 \%$ ( $n=171$ ) of patients, followed by extended coarctectomy with end-to-side aortic arch advancement in 5.3\% $(n=10)$, and in $3.2 \%(n=6)$, only aortic arch advancement was performed. Surgical techniques are shown in table 3.
Table 3. Surgical technique $(n=187)$

\begin{tabular}{|l|c|}
\hline Characteristic & $\mathbf{n}(\%)$ \\
\hline Extended coarctectomy + end-to-end anastomosis & $171(91.4)$ \\
\hline Aortic arch advancement & $6(3.2)$ \\
\hline $\begin{array}{l}\text { Extended coarctectomy with end-to-side aortic } \\
\text { advancement }\end{array}$ & $10(5.3)$ \\
\hline
\end{tabular}

Table 4. Subsequent surgery $(n=52)$

\begin{tabular}{|l|c|}
\hline Characteristic* & n (\%) \\
\hline Sternal closure & $27(51.9)$ \\
\hline Mediastinal exploration & $11(21.1)$ \\
\hline
\end{tabular}

${ }^{*}$ One lost case is reported.

The most common complication after surgery was left ventricular failure, which was observed in $90.9 \%$ ( $n=170)$ of the patients, whereas $9.1 \%(n=17)$ experienced cardiogenic shock. Table 4 shows subsequently performed surgeries.

In addition, an analysis was carried out between the surgical technique and death variables to identify whether there was any association. No significant p-value was obtained; the results are shown in table 5.

Figure 1 identifies complications that occurred in the post-operative period, with ventricular failure being the most common (55\%) followed by arterial hypertension and kidney failure requiring dialysis in 22 and 13\%, respectively. It is highly important for this information to be expounded, since it is where the physician must implement all the preventive and curative measures for not to let these complications progress to a fatal outcome, since, as we know, these are high-risk factors for these patients' mortality.

\section{Discussion}

In this research, as established by the literature, the earlier intervention in a patient with aortic coarctation was carried out, the better the prognosis was observed to be $e^{4-6}$. It should be established that although three surgical techniques have been described for neonatal patients, the most widely used since 2009 has been, by far, end-to-end coarctectomy, which has produced better results in terms of survival ${ }^{6,7}$.

Of the totality of operated patients, $91 \%$ was the above-mentioned technique used, with these patients 
Table 5. Surgical techniques versus death $(n=187)$

\begin{tabular}{|l|c|c|c|c|c|}
\hline \multirow{2}{*}{ Characteristic } & Death & Alive & \multirow{2}{*}{ P } & \multirow{2}{*}{ OR } & 95\% CI \\
\cline { 2 - 5 } & $\mathbf{1 7 ( 9 . 1 )}$ & $\mathbf{1 7 0 ( 9 0 . 1 )}$ & & & \\
\hline Extended coarctectomy + end-to-end anastomosis & $15(8.8)$ & $155(91.1)$ & 0.644 & 1.476 & $(0.306-7.121)$ \\
\hline Aortic arch advancement & $1(16.6)$ & $5(83.3)$ & 0.442 & 0.488 & $(0.054-4.436)$ \\
\hline Extended coarctectomy + end-to-side aortic arch advancement & $1(10)$ & $9(90)$ & 0.923 & 0.900 & $(0.107-7.565)$ \\
\hline
\end{tabular}

${ }^{*} \mathrm{n}(\%)$; Fisher's exact test.

OR: odds ratio; $\mathrm{Cl}$ : confidence interval; $\mathrm{p}$ : degree of significance.

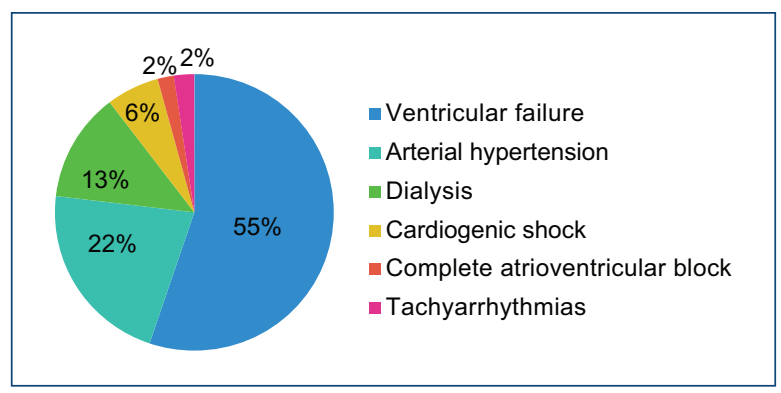

Figure 1. Post-surgical complications.

having a favorable evolution, and thus, it can be established that this is the best technique that was employed $^{7}$. It should be remembered that there are heart diseases that generate an obstruction at the level of the aortic arch and, therefore, surgical approach is with an aortic arch advancement; however, an exclusion was made for this type of pathologies because these are complex heart conditions that warranted intracardiac correction in addition to aortic correction, and this generates a higher risk of morbidity and mortality on the Risk Adjustment in Congenital Heart Surgery (RACHS)-1 scale, which would increase mortality in this study? Therefore, emphasis is made on the fact that the totality of studied subjects met the primary diagnosis of coarctation of the aorta; for example, patients who had aortic arch interruption or those who were initially intervened with catheterization and then underwent another intracardiac surgery (e.g., mitral valve plasty or pulmonary artery banding removal, etc.) were excluded from the study.

Importantly, it should be noted that there were a total of 17 deaths caused by this entity, and it should emphasized that patients may have arrived in a poor hemodynamic state and subsequently to their arrival at the hospital, and their pre-surgical, transoperative, and post-surgical management were only the reflection of a state of shock that did not improve and had a fatal outcome. In fact, $47 \%$ of these cases had an age not exceeding 1 month of life and, being a neonate therefore tends to be a factor of poor prognosis, in addition to the fact that these patients had associated pulmonary arterial hypertension and aortic arch hypoplasia ( $87.5 \%$ of neonates). On the other hand, all the patients who died had any other intracardiac and extracardiac comorbidity, except one; among these anomalies, as previously mentioned, aortic arch hypoplasia was found in 10 patients and transposition of the great arteries in four, as well as other anomalies, including mitral valve anomaly and ventricular septal defect, which are factors that tend to entail greater surgical challenge, longer hospital stay, and an uncertain prognosis, with an emphasis that patients with these conditions enter in a pre-surgical morbidity and mortality risk scale and this increases their risk of dying ${ }^{7}$.

As for the treatment provided by interventionism, both pre- and post-surgically, it is possible to identify that it has increased in congenital patients within the institute; in addition, the importance of previous catheterization should be mentioned, since as observed in the results, 58 patients underwent catheterization before the surgical procedure. Regarding recorded deaths, $82 \%$ of deceased subjects were observed not undergo hemodynamic study before surgery, which makes us wonder whether interventional treatment can help the patient before definitive treatment, if the case warrants and performing it is feasible. This will generate questions and hypotheses subsequent to this study.

As for the three patients who died and those who underwent catheterization before surgery, it should be noted that there were transoperative complications in one patient, and the other two experienced significant left ventricular failure, which precluded a favorable post-surgical evolution and outcome.

Regardless of the technique used, it should be mentioned that patients younger than 2 years benefit more from surgical intervention, since they have better 
results according to reports in the literature and that are in accordance with our reality 7,8 . As for intervention by catheterization, it has been observed that it has had better results in older children and adolescents, and although this research aimed at characterizing data of patients undergoing surgery, it should be taken into account that interventional treatment is increasingly being used ${ }^{8}$. An example is this research, since both for pre-surgical and post-surgical catheterization, a figure of 66 procedures was reached, $35 \%$ of total patients.

Other important data that should be highlighted are those yielded by electrocardiogram and X-ray information. As for the former, most subjects of the population were approximately 3 months old, and it should be remembered that, until this age, pulmonary resistances can be elevated, which can translate into an electrocardiogram with a right-skewed axis and an image that would correspond to ventricular hypertrophy, which is the aspect that was most commonly found during the research ${ }^{8,9}$.

As for X-rays, cardiomegaly is the most commonly observed finding followed by images consistent with venocapillary congestion and, in very few patients, typical signs of coarctation of the aorta, such as Roesler and inverted 3 sign, which are observed in older children, which explains why they were not found, given that median age of the sample was 3 months $^{9}$.

Among the complications, there are no findings that have not been previously discussed in the literature ${ }^{10}$. It is well recognized that these patients can develop left ventricular heart failure and systemic blood pressure elevation, which can be observed even after patient hospitalization ${ }^{11-13}$. Total number of patients with ventricular failure was $54 \%(n=117)$, which as a complication was followed by systemic arterial hypertension in $21 \%$ and, with 26 cases, acute kidney failure that required dialysis during the post-surgical period. Although it is not that common for post-surgical arrhythmias to be recorded in patients operated on for coarctation of the aorta, the most widely recorded was complete atrioventricular block (4\%).

Finally, it should be mentioned that although there were 17 cases of death reported within the period from 2009 to 2018, in the past 4 years, including the 20152018 period, only three patients have died, which has decreased the mortality rate, with special emphasis on the fact that no patient died in 2018 after coarctation of the aorta surgical correction. This information is highly important, since whenever the experience of a group of surgeons and adequate post-surgical management in the intensive care unit are analyzed, they are evaluated in terms of complications and death outcomes and, therefore, it is information that urges to continue working in the same manner at the National Institute of Cardiology and verifies the importance of appropriate patient selection for timely surgical intervention.

\section{Conclusions}

- Coarctation of the aorta is a heart disease that has to be early intervened, otherwise, the outcome can be fatal; therefore, timely intervention at a younger age generates a better survival prognosis in the pediatric population.

- Electrocardiogram and X-ray findings highly depend on the age of the patient presenting with coarctation of the aorta, and infant patients have been observed to likely have elevated lung resistances, which translates into a right-skewed QRS axis; as for X-ray, cardiomegaly is mostly observed. In older children, Roesler sign can be observed.

- The surgical technique employed with the best results in terms of operated patients and a lower mortality rate was extended coarctectomy with end-to-end anastomosis.

- Treatment by means of catheterization, prior and after surgery, is of utmost importance in the multidisciplinary management of the patient with coarctation of the aorta, since as it can be observed in this and other studies associated with the subject, management by the hemodynamics specialist is of vital importance in the prognosis of these patients.

- Among the post-surgical complications, left ventricular failure, systemic arterial hypertension acute, and kidney failure were identified, which translate into a larger number of days of hospital stay and increase morbidity and mortality in these patients.

- Survival of these patients will depend on the complexity of the heart disease, age, and, in addition, on their hemodynamic condition before, during, and after surgery.

\section{Funding}

The present investigation has not received any specific grant from agencies of public, commercial, or non-profit sectors.

\section{Conflicts of interest}

None. 


\section{Ethical disclosures}

Protection of human and animal subjects. The authors declare that no experiments were performed on humans or animals for this research.

Confidentiality of data. The authors declare that they have followed the protocols of their work center on the publication of patient data.

Right to privacy and informed consent. The authors declare that no patient data appear in this article.

\section{References}

1. Calderón-Colmenero J, Cervantes-Salazar J, García-Montes J, Attie F, Cardiología Pediátrica. 2. ${ }^{\text {a }}$ edición. Panamericana; 2012. pp 323-30.

2. Prapa M, Pepper J, Gatzoulis M. Abnormalities of the aortic root. En: Allen HD, Driscoll DJ, Shaddy RE, Feltes TF, editores. Moss and Adam's heart disease in infants, children and adolescents. $8^{\text {th }}$ ed. Philadelphia: Lippincott Williams \& Wilkins; 2013. pp 799-808.

3. Hastings L, Nichols DG. Coarctation of the aorta and interrupted aortic arch. En: Nichols DG, Cameron DE, Ungerleider RM, Nichols DG, Spevak PJ, Greeley WJ, et al. Critical heart disease in infants and children. $2^{\text {nd }}$ ed. Philadelphia: Elsevier; 2006. pp 625-648.
4. Cervantes-Salazar JL, Ramírez-Marroquín S, Benita-Bordes A, Rosas-Peralta M, Attie F. Tratamiento quirúrgico de la coartación aórtica. Resultados a largo plazo en el Instintuo Nacional de Cardiología. Arch Cardiol Mex. 2006;76(1):63-8.

5. Calderón-Colmenero J, Ramírez Marroquín S, Cervantes Salazar J. Métodos de estratificación de riesgo en la cirugía de cardiopatías congénitas. Arch Cardiol Mex. 2008;78(1):60-7.

6. Calderón-Colmenero J, Attie F. Coartación aórtica. Aspectos importantes en la evolución tardía después de la corrección. Rev Española Cardiol. 2008;61(11):1117-9.

7. Brontons D. Cardiología pediátrica y cardiopatías congénitas del niño y del adolescente. 3. ${ }^{\mathrm{a}}$ ed. Grupo CTO; 2015.

8. Zabal-Cerdeira C, García-Montes J. Intervención percutánea en la coartación de aorta en los diversos grupos de edad. En: Sousa A, Abizaid A, Martínez-Ríos M, Berrocal D, Sousa E. Intervenciones cardiovasculares SOLACI. 2. ${ }^{\text {a }}$ ed. Distribuna; 2009. pp 937-945.

9. Padalino MA, Bagatin C, Bordin G, Tua L, Francescato A, Pradegan N, et al. Surgical repair of aortic coarctation in pediatric age: A single center two decades experience. J Card Surg. 2019;34(5):256-65.

10. Costopoulos K, Philip J, Lopez-Colon D, Kaliki G, Chandran A, Bleiweis M. A single centre experience with an evolving approach for the repair of coarctation of the aorta. Cardiol Young. 2019;29(7):885-7.

11. Martínez-Villasante Alemán A, López Socarrás C, Muñoz Muñiz R, Gutiérrez-Larraya Aguado F, Arias Novas B. ¿Coartación de aorta en el recién nacido? No siempre es lo que parece: a propósito de un caso. Arch Argent Pediatr. 2020;118(1):e67-e71.

12. Hernández-González M, Solorio S, Conde-Carmona I, Rangel-Abundis A, Ledesma M, Munayer J, et al. Intraluminal aortoplasty vs. surgical aortic resection in congenital aortic coarctation. A clinical random study in pediatric patients. Arch Med Res. 2003;34(4):305-10.

13. Dijkema EJ, Leiner T, Grotenhuis HB. Diagnosis, imaging and clinical management of aortic coarctation. Heartl. 2017;103:1148-55. 